\title{
Role of a riverine plume as a nursery area for chum salmon Oncorhynchus keta
}

\author{
Masa-aki Fukuwaka*, Toshiya Suzuki \\ Research Division, National Salmon Resources Center, 2-2 Nakanoshima, Toyohira-ku, Sapporo 062-0922, Japan
}

\begin{abstract}
We examined the spatial distribution of juveniles in coastal water to assess how riverine plumes serve as nursery areas for chum salmon in early ocean life. The distribution of juveniles was restricted within a low-salinity water mass that was formed by riverine discharges. We detected 2 juvenile sizes at which distributions changed. Distributions of small juveniles ( $\leq 50 \mathrm{~mm}$ in fork length) and medium-size juveniles (50 to $75 \mathrm{~mm}$ ) were found in nearshore regions and were less affected by water temperature and salinity. Distributions of large juveniles (>75 mm) were located in waters whose salinity was 25 to 30 psu, and were less-affected by the distance from the shoreline. Results suggested that the juvenile distribution was affected by tolerance to environmental stress (high temperature or high salinity) and by refuge from fish predators. Juvenile chum salmon can use riverine plume habitats to avoid environmental stress, to search for prey patches, and to expend less energy for migration.
\end{abstract}

KEY WORDS: Riverine plume Nursery area - Ontogenetic habitat shift . Spatial distribution . Anadromous salmon - Coastal current

\section{INTRODUCTION}

Predation and environmental stress affect not only early mortality in coastal waters but also the abundance of the returning adult population of Pacific salmon Oncorhynchus spp. In anadromous salmon populations, mortality is often very high soon after juveniles enter the ocean (Pearcy 1992). Predation by fishes, birds, and mammals has been considered a major factor in early sea mortality of juvenile Pacific salmon (Bayer 1986, Beamish et al. 1992, Emmett 1997. Nagasawa 1998). Nevertheless, physical environmental stress, such as salinity and water temperature in coastal waters, also affects the abundance of adult chum populations (Mayama 1985, Blackbourn 1990). Mayama (1985) suggested that higher coastal water temperature and timing of fry release strongly affect the survival of Japanese hatchery-reared chum populations.

\footnotetext{
- Present address: Subarctic Fisheries Resources Division, Hokkaido National Fisheries Institute, 116 Katsurakoi, Kushiro 085-0802,Japan.E-mail: fukuwaka@hnf.affrc.go.jp
}

Anadromous Pacific salmon change their habitat between freshwater and marine environments with migration. Chum salmon alevin develop osmoregulatory ability, and their fry often migrate seaward soon after emergence (see reviews by Salo 1991, Clarke \& Hirano 1995). Many fry released from hatcheries also migrate seaward soon after release (Mayama et al. 1982, Kaeriyama 1986). After entering the ocean, fry are distributed in estuarine and intertidal regions. At a size of 50 to $80 \mathrm{~mm}$, fingerlings disperse in inshore regions of coastal water, and fingerlings larger than 80 $\mathrm{mm}$ eventually migrate offshore or northward around the coast of Japan (Mayama et al. 1982, Kaeriyama 1986, Irie 1990). With these ontogenetic habitat shifts, chum salmon increase salinity preference and tolerance (McInerney 1964).

Coastal waters have complex features caused by hydrodynamic effects, input from terrestrial ecosystems, and human activities. Riverine plumes are more productive than adjacent waters (Bode \& Dortch 1996, Harvey et al. 1997). Many coho and chinook salmon smolts are caught in riverine plumes off Oregon and Washington (USA) (Pearcy \& Fisher 1990, Fisher \& Pearcy 1995). Chum salmon juveniles are also caught in low salinity 
waters $(<34 \%$ ) around the coast of Japan (Irie 1990). In frontal regions of riverine plumes, zooplankton and fish eggs are accumulated (Mackas et al. 1980, Govoni et al. 1989, Grimes \& Finucane 1991, Fortier et al. 1992). The accumulation of prey in frontal regions can be utilized by Pacific salmon (Brodeur 1989). Production of Pacific salmon is affected by riverine discharges and coastal surface salinity in British Columbia and Washington State (Blackbourn 1990, Beamish et al. 1994). Coastal currents also influence recruitment of other fishes to coastal fisheries through the transport of fish larvae and organic and inorganic materials (Thomson et al. 1989, Fortier et al. 1992). Production of marine fishes is often influenced strongly by spatially and temporally variable environments in coastal waters

To assess riverine plumes as a nursery area for chum salmon in early ocean life, we examined the relationship between spatial distribution of juveniles and oceanographic environment in the Japan Sea coastal waters off Honshu. This paper aimed to (1) detect the change in spatial distribution of chum salmon juveniles with ontogeny in neritic waters and (2) identify the association between juvenile distribution and riverine plumes or other oceanographic environmental factors.

\section{MATERIALS AND METHODS}

Study site. The Japan Sea coast of Honshu, Japan, is the southern limit of chum salmon distribution in the western Pacific (Salo 1991). The northern area of the coast is characterized by broad and open sand beaches and less developed estuaries (Coastal Oceanography Research Committee, Oceanographical Society of Japan 1985). Coastal waters in the Japan Sea are strongly affected by the Tsushima Current. Currents generated by tides are relatively small. The Tsushima Current is characterized by a high temperature (minimum $8^{\circ} \mathrm{C}$ at $100 \mathrm{~m}$ depth) and high salinity (>34.1 psu) water mass flowing alongshore and northward on the continental shelf (Kawabe 1982). Riverine discharges increase in the spring due to snow melting; these discharges result in the development of riverine plumes in nearshore regions (Coastal Oceanography Research Committee, Oceanographical Society of Japan 1985).

We set a line transect from the mouth of Gakko River to the southern edge of Tobishima Island off Fukura, Yamagata Prefecture, Japan (Fig. 1). The shoreline of the southern area of the river mouth is an open sandy beach and in the northern area a rocky shore. We placed 5 sampling stations on the line transect at 2 (A), 5 (B), 10 (C), 15 (D), and 20 (E) km offshore. At these stations, water depth was 10 to $200 \mathrm{~m}$. The surface water current was observed to flow steadily northward during sampling in the study area.

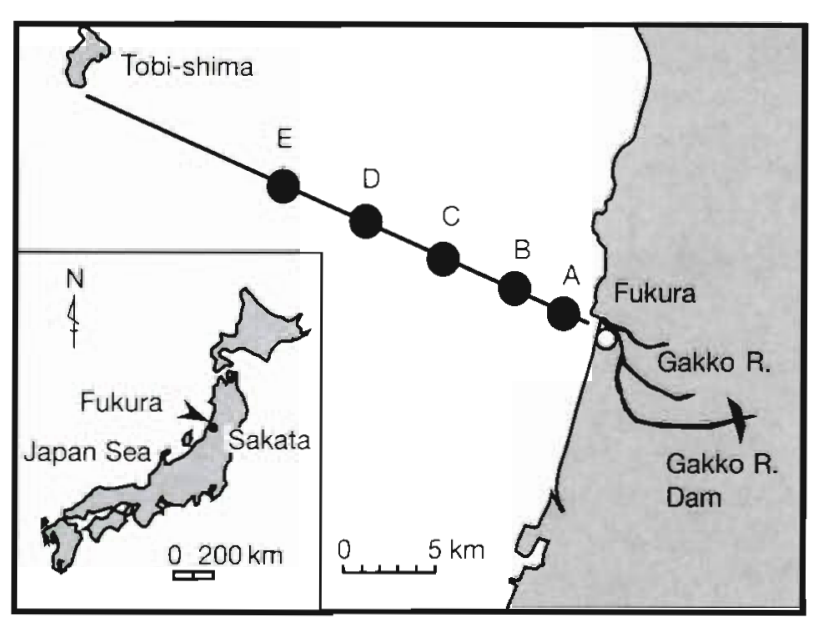

Fig. 1. Map of study site and stations for collections of chum salmon juveniles in 1993 to 1996 off Fukura, Yamagata Prefecture, Japan Sea coast

Sampling procedure. From March to May in 1993 to 1996, we collected chum salmon juveniles by surface trawls and simultaneously measured water temperature and salinity using a CTD at the sampling stations (Fig. 1). Surface trawls were towed at ca $4 \mathrm{~km} \mathrm{~h}^{-1}$ by 2 vessels parallel to the shoreline in 1 set of $30 \mathrm{~min}$ or 3 sets of $15 \mathrm{~min}$ at each station (Suzuki et al. 1994, Suzuki \& Fukuwaka 1998). The net was $8 \mathrm{~m}$ wide and $4 \mathrm{~m}$ deep at the mouth and equipped with 25 to $34 \mathrm{~mm}$ (stretched) mesh in the body and $7.5 \mathrm{~mm}$ mesh in the cod end. Latitudes and longitudes of the position of net sets were measured by a GPS. The precise distance of each net set from the shoreline was estimated as the distance from the position of net set to the nearest position on the shoreline. Collected juveniles were fixed in $10 \%$ formalin and the fork length measured in millimeters. Catch per unit effort (CPUE) was calculated as the number of collected juveniles per $30 \mathrm{~min}$ net trawl.

Detection of the difference in distribution with fish size. To evaluate how fish size intervals influenced the distribution pattern, we sorted juveniles into 13 size classes in $5 \mathrm{~mm}$ length intervals (i.e. $\leq 40,40-45$, $45-50,50-55,55-60,60-65,65-70,70-75,75-80$, $80-85,85-90,90-95$, and $>95 \mathrm{~mm}$ ). Morisita's index of interspecific correlation was estimated for the relationships in spatial distributions among the 13 size classes of juveniles (Morisita 1959). The index is less affected by number of individuals than other indices evaluating the relationship with distribution. The index ranges from -1 (completely avoid each other) to 1 (completely attract each other), and 0 value indicates that their distributions are not correlated. Cluster analysis using the complete linkage method was used to combine size classes that showed a positive relationship in their distribution 
Relationship between distribution of juveniles and environmental factors. Correlation coefficients were used to identify associations between the surface salinity $(0 \mathrm{~m})$, mean outflow of Gakko River Dam, and mean daily discharge of Mogami River for $5 \mathrm{~d}$ prior to the sampling date. These variables were used because Kawai \& Nagata (1993) found that the area covered by low salinity water was positively correlated with the sum of riverine discharge for $5 \mathrm{~d}$ prior to the observation date for 2 other rivers (Shinano and Agano) flowing into coastal waters of the Japan Sea. The relationship between riverine discharges and surface salinity was analyzed using stepwise multiple regression ( $\mathrm{p} \leq 0.05$ to add and $\mathrm{p} \geq 0.10$ to remove; Sokal $\&$ Rohlf 1995). The significance of correlation coefficients and standard partial regression coefficients was tested using the $t$-test. Outflow data of the Gakko River Dam $(15.6 \mathrm{~km}$ from the river mouth) were obtained from the Yamagata Prefectural Fisheries Experimental Station. The daily discharge of the Mogami River (the largest river closest to the study site) was obtained from the discharge table for Sagoshi Gauging Station, $11.1 \mathrm{~km}$ upstream from the river mouth (River Bureau, Ministry of Construction 1994-1997). For the structure of water masses, water temperature and salinity were averaged at $1 \mathrm{~m}$ depth intervals at each station in March, early April (1 to 15), late April (16 to 30), and May.

The randomization test of cumulative frequency was used for the difference in distribution between size classes and distance from shoreline, surface water temperature, and surface salinity (Perry \& Smith 1994, Syrjala 1996). In this test, the Cramér-von Mises test statistics and 999 permutations of random combination of 2 variants were used for the significance (Syrjara 1996). The relationships between the distribution of juveniles and the environmental factors were tested by the randomization test for cumulative functions of CPUE and stations over environmental factors (Perry \& Smith 1994). The relationships among distributions of size classes of juveniles were tested by that for cumulative functions of CPUEs over environmental factors.

\section{RESULTS}

\section{Environmental factors and CPIJE of juveniles in the coastal water}

Low salinity water off Fukura originated from discharges of rivers near the study site. Surface salinity

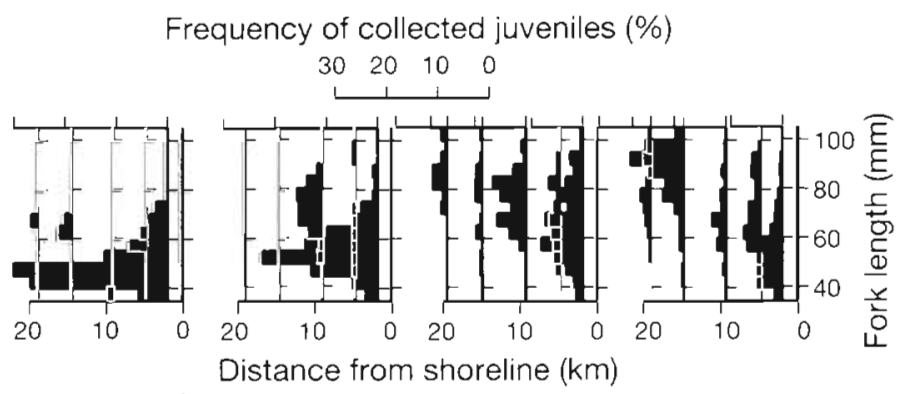

Distance from shoreline $(\mathrm{km})$
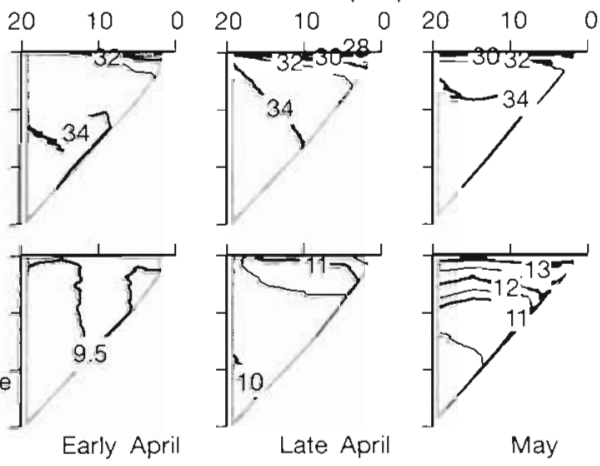

May

Fig. 2. Oncorhynchus keta. Size frequency distributions of collected chum salmon juveniles and vertical sections showing contours of salinity and water temperature in spring of 1993 to 1996 off Fukura, Japan a. Cumulative number of collected juveniles was 90 in March, 349 in early April (1 to 15), 249 in late April (16 to 30), and 403 in May

ranged from 18.5 to $34.3 \mathrm{psu}$ in March to May, and surface water temperature ranged from 8.0 to $17.6^{\circ} \mathrm{C}$ (Fig. 2). Low salinity water below 32 psu was not observed in March, but was observed in the surface layer 0 to $15 \mathrm{~km}$ offshore in early April. Low salinity water reached $20 \mathrm{~km}$ in late April, and then expanded beyond $20 \mathrm{~km}$ in May. Outflow from the Gakko River Dam was positively correlated with discharge from the Mogami River (Table 1). Surface salinity was negatively correlated with outflow from the Gakko River Dam and discharge from the Mogami River, but was more closely related with outflow from the Gakko River Dam when we calculated by stepwise multiple regression analysis (Table 1 ).

Most chum salmon juveniles were collected in the riverine plume (Fig. 2). The total number of chum salmon juveniles collected by 63 net trawls was 1091 (Table 2). The mean CPUE of juveniles was $14.7 \pm$ 24.7 SD ( $\mathrm{n}=63$ ) per 30 min net trawl. In March, the riverine plume was insufficiently developed $(<2 \mathrm{~km})$ off Fukura, and most juveniles were collected in the most nearshore ( $2 \mathrm{~km}$ station). In early April, the riverine plume was developing offshore $(<20 \mathrm{~km})$, and some juveniles were collected at $10 \mathrm{~km}$ offshore. In late April and May, the riverine plume was sufficiently developed over $20 \mathrm{~km}$ offshore, and juveniles were collected at every station from 2 to $20 \mathrm{~km}$ offshore. 
Table 1 Correlation coefficients and result of stepwise regression analysis of surface salinity off Fukura on outflow of Gakko River Dam (Japan) and riverine discharge of Mogami River (Japan) in 1993 to 1996. $\cdots p \leq 0.001$; $\cdots p \leq 0.01_{i} \cdot p \leq 0.05$

\begin{tabular}{|c|c|c|c|}
\hline & \multicolumn{2}{|c|}{ Correlation coefficients } & \multirow{2}{*}{$\begin{array}{l}\text { Standard partial } \\
\text { regression coefficient }\end{array}$} \\
\hline & Salinity & Gakko River & \\
\hline Gakko River & $-0.435^{\cdots}$ & - & $-0.481 \cdots$ \\
\hline Mogami River & $-0.325^{\circ}$ & $0.626 \cdots$ & Not entered \\
\hline
\end{tabular}

class because of the complete linkage method. The group of small juveniles consisted of 3 size classes smaller than or of $50 \mathrm{~mm}$ in fork length. The group of medium-size juveniles consisted of 5 size classes from 50 to $75 \mathrm{~mm}$ in fork length. Another group of large juveniles consisted of 5 size classes larger than $75 \mathrm{~mm}$ in fork length.
Smaller juveniles were collected in nearshore regions and larger juveniles were collected in relatively offshore regions (Fig. 2). The mean fork length of collected juveniles was between 50.0 and $84.9 \mathrm{~mm}$ in March to May of 1993 to 1996 (Table 2). In March and early April, juveniles smaller than $70 \mathrm{~mm}$ formed a large proportion of collected juveniles (Fig. 2). In late April and May, many juveniles larger than $70 \mathrm{~mm}$ were collected. On 9 of 11 sampling occasions, fork length of collected juveniles was positively correlated with the distance from shoreline to the position of net trawl (Table 2).

\section{Relationship between juvenile size and distribution}

The cluster analysis with complete linkage method shows 3 groups of juvenile size classes that were not correlated in their distribution (Fig. 3). Two linkages were constructed below a value of 0 for the Morisita's correlation index. In each group linked at positive values of the index, juvenile distribution in every size class was positively correlated with that in another size

Table 2. Oncorhynchus keta. Number of collected chum salmon juveniles, fork length (mean \pm SD) and correlation coefficient between fork length and distance from shoreline off Fukura by sampling date in 1993 to 1996. $\cdots p \leq 0.001$; $\cdot p \leq 0.05 ;$ NS: $p>0.05$

\begin{tabular}{|c|c|c|c|c|c|}
\hline Year & Date & $\begin{array}{l}\text { Number of } \\
\text { juveniles }\end{array}$ & $\begin{array}{l}\text { Fork length } \\
\qquad(\mathrm{mm})\end{array}$ & $\begin{array}{l}\text { Correlation } \\
\text { coefficient }\end{array}$ & F \\
\hline 1993 & $\begin{array}{l}\text { April } 28 \\
\text { May } 18\end{array}$ & $\begin{array}{l}88 \\
24\end{array}$ & $\begin{array}{l}72.8 \pm 13.7 \\
59.8 \pm 9.4\end{array}$ & $\begin{array}{l}0.460 \\
0.460\end{array}$ & $\begin{array}{l}23.1^{\circ} \\
5.92^{\circ}\end{array}$ \\
\hline 1994 & $\begin{array}{l}\text { March } 22 \\
\text { April } 7 \\
\text { April } 21\end{array}$ & $\begin{array}{l}90 \\
81 \\
68\end{array}$ & $\begin{array}{l}50.0 \pm 8.4 \\
56.1 \pm 8.3 \\
58.6 \pm 9.6\end{array}$ & $\begin{array}{l}0.378 \\
0.417 \\
0.527\end{array}$ & $\begin{array}{l}14.6^{\cdots} \\
16.7^{\cdots} \\
25.4^{\cdots}\end{array}$ \\
\hline 1995 & $\begin{array}{l}\text { April } 12 \text { and } 14 \\
\text { April } 28 \text { and } 29 \\
\text { May } 9 \text { and } 10\end{array}$ & $\begin{array}{r}71 \\
59 \\
115\end{array}$ & $\begin{array}{l}52.4 \pm 11.1 \\
65.4 \pm 15.8 \\
74.5 \pm 13.6\end{array}$ & $\begin{array}{l}0.530 \\
0.132 \\
0.140\end{array}$ & $\begin{array}{l}27.0 \cdots \\
1.01 \mathrm{NS} \\
2.70 \mathrm{NS}\end{array}$ \\
\hline 1996 & $\begin{array}{l}\text { April } 9 \\
\text { April } 23 \\
\text { May } 12 \text { and } 14\end{array}$ & $\begin{array}{r}197 \\
34 \\
264\end{array}$ & $\begin{array}{l}63.2 \pm 11.1 \\
84.9 \pm 9.9 \\
73.8 \pm 18.9\end{array}$ & $\begin{array}{l}0.597 \\
0.392 \\
0.889\end{array}$ & $\begin{array}{l}108^{\cdots} \\
5.82^{\bullet} \\
984^{\cdots}\end{array}$ \\
\hline Pooled & & 1091 & $66.6 \pm 16.3$ & 0.674 & $906^{\cdots}$ \\
\hline
\end{tabular}

\section{Relationship between distribution of juveniles and environmental factors}

The distribution of small juveniles was largely restricted to the nearshore region off Fukura. A large portion of small juveniles ( $\leq 50 \mathrm{~mm}$ ) was collected at the station nearest to the shore (Fig. 4A). The distribution of small juveniles was significantly different from the distribution of distance from shoreline to net trawls (Table 3). Most small juveniles were collected at below $13^{\circ} \mathrm{C}$ surface water temperature (Fig. $4 \mathrm{~B}$ ), but the distribution of small juveniles was not different from that of water temperature (Table 3 ). Cumulative frequency of small juveniles increased in a similar pattern as salinity (Fig, 4C, Table 3 ).

The distribution of medium-size (50 to $75 \mathrm{~mm}$ ) juveniles was not significantly different from that of small juveniles (Table 4), but medium-size juveniles were collected in the offshore area more often than small juveniles (Fig. 4A). Most medium-size juveniles were collected within 0 to $10 \mathrm{~km}$ offshore (Fig. 4A). The distribution of medium-size juveniles was significantly different from the distribution of distance from shoreline to net trawls (Table 3). Most medium-size juveniles were collected in stations with surface water temperature below $14^{\circ} \mathrm{C}$ (Fig. $4 \mathrm{~B}$ ), but their distribution was not significantly different from that of temperature (Table 3). Cumulative frequency of medium-size juvenile CPUE increased in a similar pattern as salinity and as that of small juveniles (Fig. $4 \mathrm{C}$, Tables $3 \& 4$ ).

The distribution of large (>75 $\mathrm{mm}$ ) juveniles was restricted to a narrow range of salinity and was different from those of small ( $\leq 50 \mathrm{~mm}$ ) and medium-size (50 to $75 \mathrm{~mm}$ ) juveniles in relationships between distribution and environmental factors. The distribution of large juveniles was not significantly different from that of distance from shoreline to net trawls 


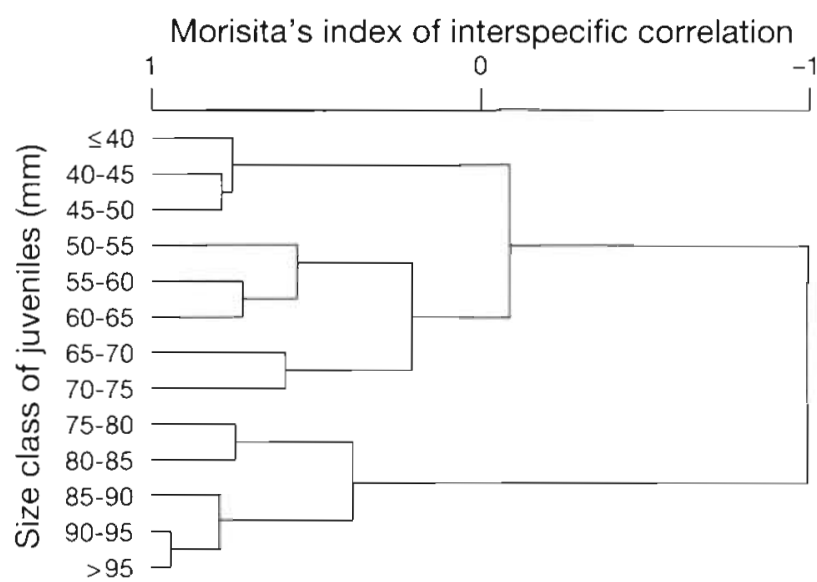

Fig. 3. Dendrogram constructed by cluster analysis of similarity among distribution patterns of chum salmon juvenile size classes. Morisita's index of interspecific correlation was used for the similarity

(Fig. 4A, Table 3), and it was different from those of small and medium-size juveniles (Table 4). A large portion of large juveniles was collected in the range of surface salinity from 25 to 30 psu (Fig. 4C). The distribution of large juveniles was significantly different from those of salinity and small juveniles (Tables $3 \&$ 4). Most large juveniles were also collected in stations with surface water temperature below $14^{\circ} \mathrm{C}$, and many large juveniles were collected near $11^{\circ} \mathrm{C}$ (Fig. 4B). The distribution of large juveniles was not significantly different from those of water temperature, small juveniles, and medium-size juveniles (Tables 3 \& 4).

\section{DISCUSSION}

\section{Developmental stages and juvenile distributions}

Distributions of fry and fingerlings of chum salmon differed off Fukura. We found 3 size groups whose distributions were not correlated with each other. Each group was sequentially linked to adjacent size classes of juveniles. One group included juveniles smaller than

Table 3. CPUE (mean \pm SD) and results (probability values) of randomized test for the associations between distance from shoreline surface water temperature and salinity and distributions of 3 size classes of chum salmon juveniles collected off Fukura, Japan Sea. n: cumulative number of net trawls

\begin{tabular}{|lccccc|}
\hline $\begin{array}{l}\text { Size class } \\
(\mathrm{mm})\end{array}$ & $\begin{array}{c}\text { CPUE } \\
\text { (no./30 min traw) }\end{array}$ & $\begin{array}{c}\text { Distance from } \\
\text { shoreline }\end{array}$ & $\begin{array}{c}\text { Surface water } \\
\text { temperature }\end{array}$ & $\begin{array}{l}\text { Surface } \\
\text { salinity }\end{array}$ & n \\
\hline$\leq 50$ & $2.69 \pm 8.4$ & 0.001 & $>0.05$ & $>0.05$ & 63 \\
$50-75$ & $7.94 \pm 15.5$ & 0.001 & $>0.05$ & $>0.05$ & 63 \\
$>75$ & $4.33 \pm 12.0$ & $>0.05$ & $>0.05$ & 0.004 & 63 \\
\hline
\end{tabular}
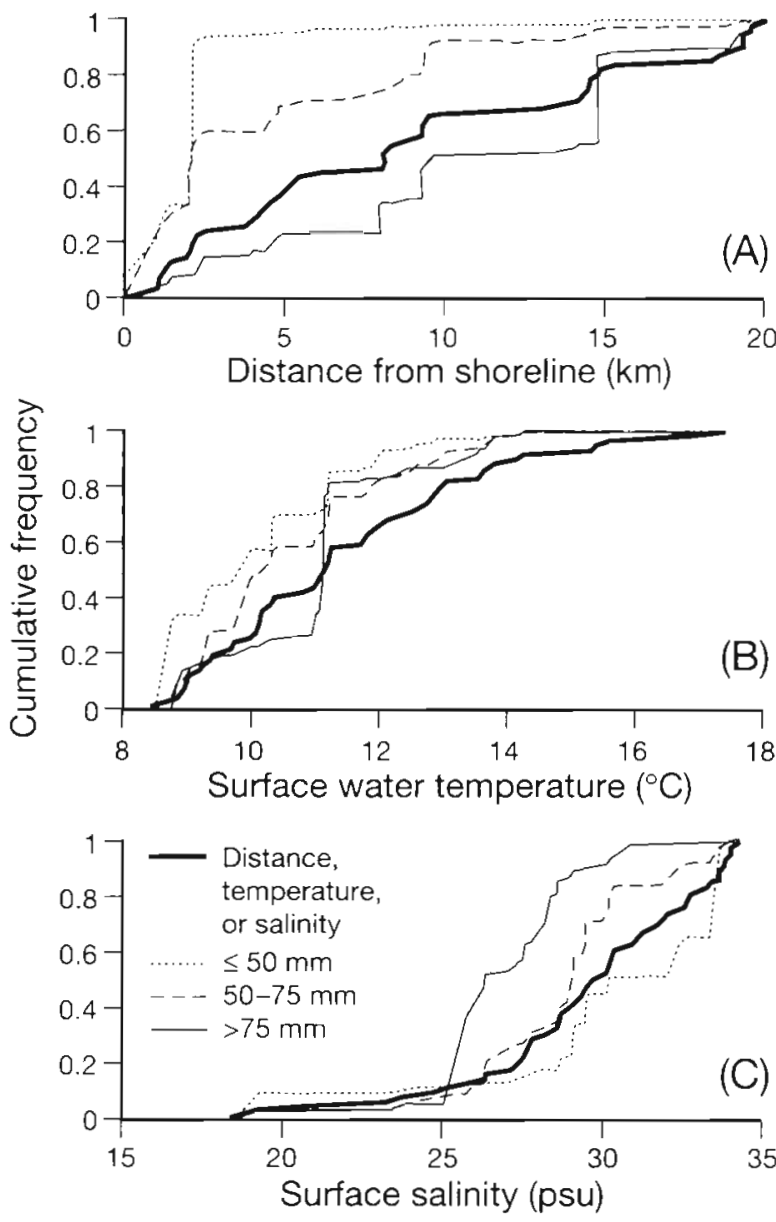

Fig. 4. Relationships between cumulative frequencies of chum salmon CPUE for 3 size classes and cumulative frequency of observed and fixed environmental factors for the stations: (A) distance from shoreline, (B) surface water temperature, and $(\mathrm{C})$ surface salinity

$50 \mathrm{~mm}$ in fork length, another group included juveniles of fork length from 50 to $75 \mathrm{~mm}$, and the other included juveniles larger than $75 \mathrm{~mm}$. In the early sea life of chum salmon, fry ( 30 to $50 \mathrm{~mm}$ in fork length) are distributed in estuarine or intertidal regions, small fingerlings of 50 to $80 \mathrm{~mm}$ disperse in inshore regions of coastal water, and fingerlings larger than $80 \mathrm{~mm}$ migrate offshore or northward (Mayama et al. 1982, Kaeriyama 1986, Irie 1990). The swimming ability of fishes increases with their size (Beamish 1978). Skeletal structure related to swimming ability is intensified considerably in the fingerling stage with 50 to $80 \mathrm{~mm}$ fork length, and is completed in the fingerling stage with 80 to $120 \mathrm{~mm}$ fork length of chum salmon (Kaeriyama 1986). Changes in juvenile distribution are attributed to an increase of swimming ability with development. 
Table 4. Results (probability values) of randomized test for difference in associations between distribution and distance from shoreline, surface water temperature, and salinity among 3 size classes of chum salmon juveniles off Fukura, Japan Sea

\begin{tabular}{|c|c|c|c|c|c|c|c|c|c|}
\hline \multirow{2}{*}{$\begin{array}{l}\text { Size class } \\
(\mathrm{mm})\end{array}$} & \multicolumn{3}{|c|}{ Distance from shoreline } & \multicolumn{3}{|c|}{ Water temperature } & \multicolumn{3}{|c|}{ Salinity } \\
\hline & $\leq 50$ & $50-75$ & $>75$ & $\leq 50$ & $50-75$ & $>75$ & $\leq 50$ & $50-75$ & $>75$ \\
\hline$\leq 50$ & - & $>0.05$ & 0.001 & - & $>0.05$ & $>0.05$ & - & $>0.05$ & 0.016 \\
\hline $50-75$ & - & - & 0.006 & - & - & $>0.05$ & - & - & $>0.05$ \\
\hline$>75$ & - & - & - & - & - & - & - & - & - \\
\hline
\end{tabular}

Chum salmon fry may find refuge from marine predators in the shallow onshore area, and fingerlings may select an appropriate habitat for feeding or growing in the relatively offshore area. Fry are distributed in estuaries or onshore regions of open coasts (Healey 1979, Mayama et al. 1982). Larger juveniles are distributed in more offshore regions in coastal waters (Kaeriyama 1986, Irie 1990, Suzuki et al. 1994). Juvenile size was often correlated with distance from shoreline off Fukura. Small juveniles ( $\leq 50 \mathrm{~mm}$ ) and medium-size juveniles (50 to $75 \mathrm{~mm}$ ) had a distribution that was significantly related to the inshore region, but they were not affected by surface water temperature and salinity. Medium-size juveniles were distributed relatively further offshore than small juveniles. The distribution of large juveniles was less affected by distance from shoreline and strongly affected by surface salinity. Salo (1991) reviewed that the of fshore movement of chum salmon juveniles coincides with the decline of inshore prey resources when the fishes have grown to a size that allows them to feed upon larger neritic organisms and avoid predators. On the westerm coast of North America, the restriction of prey availability in estuaries limits chum salmon populations (Healey 1979, Wissmar \& Simenstad 1988). Piscivorous fishes and birds prey extensively on juvenile salmon in estuaries (Parker 1971, Bayer 1986, Beamish et al. 1992). Although predation by birds on fish is greater in shallower depths, small prey fish are distributed in shallow waters because of predatory large fish (Safina \& Burger 1985, Crowder et al. 1997). In some fishes inhabiting sand beaches, the positive relationship between fish size and depth reduceds the predation on smaller fishes by fish predators inhabiting deeper waters (Ruiz et al. 1993, Gibson et al. 1995). Chum salmon fingerlings obtain sufficient swimming ability to avoid fish predators, to search for prey organisms, and to select appropriate habitats.

\section{Physical environment and juvenile distribution in the coastal water}

The difference in juvenile distributions among size classes could be caused by differences in habitat selec- tion. While smaller juveniles were restricted to inshore regions and were observed over a wide range of salinities, larger juveniles were distributed over a narrow range of salinities around 28 psu. Chum salmon have osmoregulatory ability in their early life and their juveniles increase salinity preference temporally, which relates to the ontogenetic habitat shift in their migration (see review by Clarke \& Hirano 1995). While juveniles tolerate unusually high salinity waters ( $<48$ psu), they prefer low salinity water below $12 \% \mathrm{Cl}$. (ca 22 psu in salinity) (McInerney 1964). Growth rates of juveniles of $1 \mathrm{~g}$ in body weight (ca $50 \mathrm{~mm}$ in fork length) decrease in highly saline waters of 32 psu (Koshiishi 1986). This indicates that highly saline water is not preferred by chum salmon juveniles and is inappropriate for their growth. Larger juveniles selected actively for water masses around 28 psu in salinity in the coastal water. Smaller juveniles stayed in inshore areas, and would have less ability of habitat selection in offshore regions of the coastal water.

The upper limits of water temperature for the distribution of chum salmon juveniles are determined by their physiological tolerance. Although a significant relationship between water temperature and juvenile distribution was not observed, most juveniles were distributed below $14^{\circ} \mathrm{C}$ surface water temperature off Fukura. Chum salmon juveniles have previously been observed to be mostly distributed in water masses below $14^{\circ} \mathrm{C}$ water temperature in coastal waters (Kaeriyama 1986, Irie 1990). Chum salmon juveniles decrease their feeding efficiency in rearing experiments in a water temperature of $15^{\circ} \mathrm{C}$ (Kaeriyama 1986). Mayama (1985) suggested that coastal water temperature at release time strongly affects the abundance of the hatchery-reared chum salmon population in Japan.

\section{Function of riverine plumes}

The riverine plume provides an appropriate habitat not only for salinity tolerance but also for higher concentration of food for juvenile chum salmon. The riverine plume developed from early April to May off Fukura. Juveniles dispersed offshore in the riverine 
plume. Primary production is higher in a riverine plume than in adjacent waters because of the input of nutrients originating from the land (Bode \& Dortch 1996, Harvey et al. 1997). Zooplankton, fish eggs, and fish larvae are often accumulated in the frontal region of riverine plumes (Mackas et al. 1980, Govoni et al. 1989, Grimes \& Finucane 1991). Pacific salmon juveniles and zooplankton are abundant in the frontal region of estuarine and riverine plumes, and juvenile salmon are attracted to the higher concentration of prey organisms (Brodeur 1989, St. John et al. 1992). Chum salmon juveniles prey on zooplankton and fish larvae off Fukura (Suzuki et al. 1994, Suzuki \& Fukuwaka 1998). Large juveniles (>75 mm) were concentrated from 25 to 30 psu surface salinity off Fukura Large juveniles selected frontal regions of riverine plumes where there is a high probability that juveniles encounter a patch of prey organisms.

The extension of the riverine plume might decrease the predation rate of juvenile chum salmon by marine predators. In British Columbia and Washington State riverine discharge was negatively correlated with marine survival of chum, pink, and sockeye salmon (Oncorhynchus keta, O. gorbuscha, and O. nerka) (Blackbourn 1990, Beamish et al. 1994). River lamprey Lampetra ayresi prey extensively on juvenile salmon in the Fraser River plume (Beamish \& Neville 1995). Off Fukura, a slightly digested juvenile of chum salmon was observed in stomach contents of masu salmon smolt $O$. masou caught using a trawl net (authors' unpubl. data). However, chinook salmon smolts $O$ tshawytscha released in the marine zone are exposed to more bird and fish predators than smolts released in transition, estuarine, and river zones (Macdonald et al. 1988). Hartt \& Dell (1986) thought that the nearshore distribution of chum, pink, and sockeye salmon juveniles minimized the overlap with oceanic predators. In addition, Nagasawa (1998) concluded in his review that predation by fishes did not appear to be an important factor controlling Japanese chum salmon populations.

Chum salmon juveniles are transported northward by the Tsushima Current in the Japan Sea coastal water. Large juveniles (>75 mm) were distributed relatively offshore within the riverine plume. On the Hokkaido coast of Japan Sea, chum salmon juveniles around $70 \mathrm{~mm}$ have been observed to begin to migrate northward along the coast (Mayama et al. 1982). Off Fukura, surface water flowed alongshore and northward in every net set (pers. obs.). A branch of the Tsushima Current flows northward and alongshore in the region landward of $200 \mathrm{~m}$ depth on the Japan Sea coast (Kawabe 1982). The Shinano-Agano River plume spreads mainly northward and alongshore in the nearshore region within $10 \mathrm{~km}$ offshore and shallower than $100 \mathrm{~m}$ in depth, which was affected by the coastal current (Kawai \& Nagata 1993). Off Oregon, coho and chinook smolts released in the Columbia River are transported in the riverine plume by the coastal jet during May and June (Pearcy \& Fisher 1988, Fisher \& Pearcy 1995). The migration route of Fraser River sockeye salmon has been explained by surface currents and random swimming behavior of fish (Walter et al. 1997). The alongshore coastal current acts as an alongshore conduit and cross-shore barrier to the transport of biomass and other materials over the continental margins (Thomson et al. 1989).

In summary, distributions of chum salmon juveniles in the Japan Sea coastal water differed among their developmental stages: fry ( $\leq 50 \mathrm{~mm})$, small fingerlings (50 to $75 \mathrm{~mm}$ ), and large fingerlings (>75 mm). Juvenile distributions were mostly within a riverine plume, and were determined by distance from shoreline or by surface salinity when surface water temperature ranged from 8 to $14^{\circ} \mathrm{C}$. These oceanographic environments are affected by coastal water current, climate, and water utilization on the land. Our results suggested that juvenile distribution was affected by the tolerance to environmental stress (high temperature or high salinity) and by the refuge from fish predators. Functions of the distribution within the riverine plume are to avoid environmental stress, to search for prey patches, and to use less energy for migration.

Acknowledgements. We thank $\mathrm{H}$. Kasahara, W. Honto, T Sato, H. Kageyama, S. Wakabayashi, and T. Matsumiya for their help in data collections, and S. Kagaya and M. Takahashi for their help in sample collections. We are also grateful to K. Hirakawa and M. Hirai for valuable discussions.

\section{LITERATURE CITED}

Bayer RD (1986) Seabird near an Oregon estuarine salmon hatchery in 1982 and during the 1983 El Nino. Fish Bull US $84: 279-286$

Beamish FWH (1978) Swimming capacity. In: Hoar WS, Randall DJ (ed) Fish physiology, Vol VII. Academic Press, New York, p 101-187

Beamish RJ, Neville CEM (1995) Pacific salmon and Pacific herring mortalities in the Fraser River plume caused by river lamprey (Lampetra ayresi). Can J Fish Aquat Sci 52:644-650

Beamish RJ, Thomson BL, McFarlane GA (1992) Spiny dogfish predation on chinook and coho salmon and the potential effects on hatchery-produced salmon. Trans Am Fish Soc 121:444-455

Beamish RJ, Neville CEM, Thomson BL, Harrison PJ, St John $M$ (1994) A relationship between Fraser River discharge and interannual production of Pacific salmon (Oncorhynchus spp.) and Pacific herring (Clupea pallasi) in the Strait of Georgia. Can J Fish Aquat Sci 51:2843-2855

Blackbourn DJ (1990) Comparison of release size and environmental data with the marine survival rates of some wild and enhanced stocks of pink and chum salmon in British Columbia and Washington State. In: Knudsen 
PA (ed) 14th Northeast Pacific pink and chum salmon workshop. Washington State Department of Fisheries, Olympia, p 82-87

Bode A, Dortch Q (1996) Uptake and regeneration of inorganic nitrogen in coastal waters influenced by the Mississippi River: spatial and seasonal variations. J Plankton Res $18: 2251-2268$

Brodeur RD (1989) Neustonic feeding by juvenile salmonids in coastal waters of the Northeast Pacific. Can J Zool. 67 : $1995-2007$

Clarke WC, Hirano T (1995) Osmoregulation. In: Groot C. Margolis L, Clarke WC (eds) Physiological ecology of Pacific salmon. UBC Press, Vancouver, p 317-377

Coastal Oceanography Research Committee, Oceanographical Society of Japan (ed) (1985) Coastal oceanography of Japanese Islands. Tokai University Press, Tokyo

Crowder LB, Squires DD, Rice JA (1997) Nonadditive effects of terrestrial and aquatic predators on juvenile estuarine fish. Ecology 78:1796-1804

Emmett RL (1997) Estuarine survival of salmonids: the importance of interspecific and intraspecific predation and competition. In: Emmett RL, Schiewe MH (eds) Estuarine and ocean survival of Northeastern Pacific salmon: Proceedings of the workshop. US Dept Commerce, NOAA. Tech Memo No. NMFS-NWFSC-29, p 147-158

Fisher JP, Pearcy WG (1995) Distribution, migration, and growth of juvenile chinook salmon. Oncorhynchus tshawytscha, off Oregon and Washington. Fish Bull US 93: $274-289$

Fortier L, Levasseur ME, Drolet R, Therriault JC (1992) Export production and the distribution of fish larvae and their prey in a coastal jet frontal region. Mar Ecol Prog Ser 85: 203-218

Gibson RN, Robb L, Burrows MT, Ansell AD (1995) Tidal, diel and longer term changes in the distribution of fishes on a Scottish sandy beach. Mar Ecol Prog Ser 130:1-17

Govoni JJ, Hoss DE, Colby DR (1989) The spatial distribution of larval fishes about the Mississippi River plume. Limnol Oceanogr 34:178-187

Grimes CB, Finucane JH (1991) Spatial distribution and abundance of larval and juvenile fish, chlorophyll and macrozooplankton around the Mississippi River discharge plume, and the role of the plume in fish recruitment. Mar Ecol Prog Ser 75:109-119

Hartt AC, Dell MB (1986) Early oceanic migrations and growth of juvenile Pacific salmon and steelhead trout. Int North Pac Fish Comm Bull No. 46

Harvey M, Therriault JC, Simad N (1997) Late-summer distribution of phytoplankton in relation to water mass characteristics in Hudson Bay and Hudson Strait (Canada). Can J Fish Aquat Sci 54:1937-1952

Healey MC (1979) Detritus and juvenile salmon production in the Nanaimo Estuary: I. Production and feeding rates of juvenile chum salmon (Oncorhynchus keta). J Fish Res Bd Can 36:488-496

Irie T (1990) Ecological studies on the migration of juvenile chum salmon, Oncorhynchus keta, during early ocean life. Bull Seikai Natl Fish Res Inst 68:1-142

Kaeriyama M (1986) Ecological study on early life of the chum salmon, Oncorhynchus keta (Walbaum). Sci Rep Hokkaido Salmon Hatchery 40:31-92

Kawabe $M$ (1982) Branching of the Tsushima Current in the Japan Sea; Part I. Data analysis. J Oceanogr Soc Jpn 38 95-1.07

Kawai $H_{1}$ Nagata $H$ (1993) Mixing process of the Shinano and other rivers effluent with seawater. Bull Jpn Sea Natl Fish Res Inst 43:9-54
Koshiishi Y (1986) Effect of salinity on food untake, growth and feed efficiency of chum salmon, Oncorhynchus keta (Walbaum), and ayu, Plecoglossus altivelis Temminck et Schlegel. Bull Jpn Sea Reg Fish Res Lab 36:1-14

Macdonald JS, Levings CD. McAllister CD. Fagerlund UHM, McBride JR (1988) A field experiment to test the importance of estuaries for chinook salmon (Oncorhynchus tshawytscha) survival: short-term results. Can J Fish Aquat Sci 45:1366-1377

Mackas DL, Louttit GC, Austin MJ (1980) Spatial distribution of zooplankton and phytoplankton in British Columbia coastal waters. Can J Fish Aquat Sci 37:1476-1487

Nayama $H$ (1985) Technical innovations in chum salmon enhancement with special reference to fry condition and timing of release. In: Sindermann CJ (ed) Proceedings of the eleventh US-Japan meeting on aquaculture, salmon enhancement, Tokyo, Japan, October 19-20, 1982. NOAA Tech Rep NMFS 27:83-86

M.ayama H, Kato M, Seki J, Shimizu l (1982) Studies on the chum salmon released in the Ishikari River System-I. On the seaward migration and inshore distributions of liberated fry in 1979. Sci Rep Hokkaido Salmon Hatchery 36:1-17

McInerney JE (1964) Salinity preference: an orientation mechanism in salmon migration. J Fish Res Bd Can 21. $995-1018$

Morisita M (1959) Measuring of interspecific association and similarity between communities. Mem Fac Sci Kyushu Univ Ser E (Biol) 3:65-80

Nagasawa K (1998) Fish and seabird predation on juvenile chum salmon (Oncorhynchus keta) in Japanese coastal waters, and an evaluation of the impact. N Pac Anadr Fish Comm Bull 1:480-495

Parker RR (1971) Size selective predation among juvenile salmonid fishes in a British Columbia inlet. J Fish Res Bd Can 28:1503-1510

Pearcy WG (1992) Ocean ecology of North Pacific salmonids University of Washington Press, Seattle

Pearcy WG, Fisher JP (1988) Migrations of coho salmon, Oncorhynchus kisutch, during their first summer in the ocean. Fish Bull US 86:173-195

Pearcy WG, Fisher JP (1990) Distribution and abundance of juvenile salmonids off Oregon and Washington, 1981-1985 NOAA Tech Rep NMFS 93

Perry RI, Smith SJ (1994) Identifying habitat associations of marine fishes using survey data: an application to the northwest Atlantic. Can J Fish Aquat Sci 51:589-602

River Bureau, Ministry of Construction (ed) (1994-1997) Ryuryo nenpyo. Nihon Kasen Kyoka1, Tokyo

Ruiz GM. Hines AH, Posey MH (1993) Shallow water as a refuge habitat for fish and crustaceans in non-vegetated estuaries: an example from Chesapeake Bay. Mar Ecol Prog Ser 99:1-16

Safina C, Burger $J$ (1985) Common tern foraging: seasonal trends in prey fish densities and competition with bluefish. Ecology 66:1457-1463

Salo EO (1991) Life history of chum salmon (Oncorhynchus keta). In: Groot C, Margolis L (eds) Pacific salmon life histories. UBC Press, Vancouver, p 231-309

Sokal RR, Rohlf FJ (1995) Biometry, 3rd edn. WH Freeman and Company, New York

St John MA, Macdonald JS, Harrison PJ, Beamish RJ, Choromanski E (1992) The Fraser River plume: some preliminary observations on the distribution of juvenile salmon, herring, and their prey. Fish Oceanogr 1:153-162

Suzuki T, Fukuwaka M (1998) Variation in prey size selectivity of fingerling chum salmon (Oncorhynchus keta) in sea life: effects of stomach fullness and prey abundance. 
N Pac Anadr Fish Comm Bull 1:138-145

Suzuki T, Fukuwaka M, Shimizu I, Seki J, Kaeriyama M, Mayama H (1994) Feeding selectivity of juvenile chum salmon in the Japan Sea coast of northern Honshu. Sci Rep Hokkaido Salmon Hatchery 48:11-16

Syrjala SE (1996) A statistical test for a difference between the spatial distributions of two populations. Ecology 77:75-80

Thomson RE, Hickey BM, LeBlond PH (1989) The Vancouver Island coastal current: fisheries barrier and conduit. In: Beamish RJ, McFarlane GA (eds) Effects of ocean vari-

Editorial responsibility: Otto Kinne (Editor), Oldendorf/Luhe, Germany ability on recruitment and an evaluation of parameters used in stock assessment models. Can Spec Publ Fish Aquat Sci 108:265-296

Walter EE, Scandol JP, Healey MC (1997) A reappraisal of the ocean migration patterns of Fraser River sockeye salmon (Oncorhynchus nerka) by individual-based modelling. Can J Fish Aquat Sci 54:847-858

Wissmar RC, Simenstad CA (1988) Energetic constraints of juvenile chum salmon (Oncorhynchus keta) migrating in estuaries. Can J Fish Aquat Sci 45:1555-1560

Submitted: May 5, 1998; Accepted: July 7, 1998

Proofs received from author(s): October 16, 1998 